\title{
Rickettsial meningitis
}

\author{
Inês Salva, ${ }_{1}^{1}$ Rita de Sousa, ${ }^{2}$ Catarina Gouveia ${ }^{3}$
}

${ }^{1}$ Department of Pediatrics, Hospital de Dona Estefânia, Lisbon, Portugal

${ }^{2}$ National Institute of Health Dr. Ricardo Jorge, Lisbon, Portugal

${ }^{3}$ Infectious Diseases Unit, Hospital de Dona Estefânia, Lisbon, Portugal

\section{Correspondence to} Dr Inês Salva, ines.salva@gmail.com

Accepted 10 February 2014

\section{CrossMark}

To cite: Salva I, de Sousa R, Gouveia C. BMJ Case Rep Published online: [please include Day Month Year] doi:10.1136/bcr-2013203283

\section{SUMMARY}

Rickettsial infections are common in southern Europe and the most frequent and lethal type is Mediterranean spotted fever, caused by Rickettsia conorii. The disease is usually characterised by the classical triad of fever, eschar and rash, and is generally a mild disease in children. Complications including neurological involvement are rarely described. We report an unusual case of meningitis in an 18-year-old man, presenting during summer with fever and persistent headache. The cerebrospinal fluid analysis revealed increased cellularity (107 cells/ $\mathrm{LL}$ ), hypoglycorrhachia (50\% of glycaemia) and hyperproteinorrhachia (284 mg/dL). Rickettsial infection was confirmed by serology and the patient was treated with doxycycline, with a favourable outcome. The patient's pet squirrel and/or associated vectors might be involved in the transmission of Rickettsia spp. This case underlines the importance of a high clinical suspicion and the benefits of early empirical treatment when facing compatible epidemiological contexts.

\section{BACKGROUND}

Rickettsial infections are caused by obligate intracellular organisms, carried by arthropods, and are divided into two main groups: the spotted fever group and the typhus group. ${ }^{12}$

In the Mediterranean basin, the most common disease-causing Rickettsia species within the spotted fever group are Rickettsia conorii, Rickettsia sibirica mongolitimonae and Rickettsia slovaca, although several other species of Rickettsia have been identified over the years, including Rickettsia raoultii, Rickettsia rioja, Rickettsia helvetica, Rickettsia massiliae, Rickettsia monacensis and Rickettsia felis. ${ }^{3-5}$

In Portugal, as in the remaining southern Europe, the most prevalent rickettsiosis is Mediterranean spotted fever. ${ }^{67}$ Reported incidence was 8.4/10 000 inhabitants between 1989 and $2005 .^{7}$ The classical presentation is fever, headache and rash that are caused by a process of generalised microvasculitis, usually associated with an eschar. ${ }^{189}$ Most symptoms are non-specific and the severity of presentation varies widely. ${ }^{1}$ The mortality rate is $2.5 \%$ on average, although in Portugal reports indicate a much higher rate $(20-30 \%))^{79}$

Besides variation in severity, there is an increasing number of reports describing infections by diverse Rickettsia spp with atypical presentations such as acute myocarditis and atrioventricular block, interstitial pneumonitis, meningitis and encephalitis. ${ }^{10-15}$ We report a rare case of meningitis in the absence of the typical general symptoms.

\section{CASE PRESENTATION}

A previously healthy 18-year-old male adolescent presented at a paediatric hospital in Lisbon with an 11-day history of progressive biparietal headache refractory to symptomatic therapy (paracetamol and ibuprofen). The patient also had low-grade fever (axillary temperature of $37.5^{\circ} \mathrm{C}$ ). He had been medicated as an outpatient with clarithromycin $500 \mathrm{mg}$ every $12 \mathrm{~h}$ during the previous 5 days.

The patient reported contact with a dog and a pet squirrel but did not recall any recent tick or flea bite.

Physical examination on admission revealed arterial pressure of $125 / 75 \mathrm{~mm} \mathrm{Hg}$, heart rate $75 \mathrm{bpm}$, axillary temperature $37^{\circ} \mathrm{C}$ and a normal neurological examination (including absence of meningismus). No lymphadenopathy, rash or eschar was noted.

\section{INVESTIGATIONS}

Laboratory studies showed $5700 / \mu \mathrm{L}$ leucocytes $(4500-11000 / \mu \mathrm{L}), \quad 53.9 \%$ neutrophils, normal haemoglobin and platelet count, negative sedimentation rate and $\mathrm{C}$ reactive protein $(0.07 \mathrm{mg} / \mathrm{dL}$; reference value $<2 \mathrm{mg} / \mathrm{dL}$ ), no renal dysfunction and normal transaminase values.

Cerebrospinal fluid (CSF) analysis showed pleocytosis $(107 \mathrm{cells} / \mu \mathrm{L}$ with lymphocyte predominance; reference value $<10$ cells $/ \mu \mathrm{L}$ ), hypoglycorrhachia $(36 \mathrm{mg} / \mathrm{dL}$ for a glycaemia of $84 \mathrm{mg} / \mathrm{dL}$; reference value $\geq 60 \%$ of glycaemia) and hyperproteinorrhachia $(284 \mathrm{mg} / \mathrm{dL}$; reference value $\leq 45 \mathrm{mg} / \mathrm{dL})$.

Head CT and MRI showed right frontal inflammatory sinusopathy and were otherwise normal.

Cerebral spinal fluid and blood cultures were negative. Investigation for herpesvirus, enterovirus, arbovirus, Borrelia and Mycobacterium tuberculosis was negative. Serological blood studies including HIV, venereal disease research laboratory, Mycoplasma, Brucella and Bartonella excluded acute infection. Chest radiography was normal and the tuberculin intradermal reaction was negative.

Intravenous ceftriaxone was administered for 1 week with no improvement.

The diagnosis was confirmed by serology (immunofluorescence assay) that showed a seroconversion, with an eightfold increase of $\operatorname{IgG}$ antibodies for $R$ conorii in 2 weeks (with titres of 128 and 1024). PCR for Rickettsia in the blood specimen was negative.

The squirrel's blood was also tested for the presence of rickettsial infection by PCR and serology. No rickettsial DNA was detected but serology revealed an $\operatorname{IgG}$ titre of 64 , considered positive. No fleas or ticks were collected from the squirrel.

Treatment was changed to doxycycline.

\section{DIFFERENTIAL DIAGNOSIS}

Our patient presented with meningitis and was empirically treated with ceftriaxone with no 
improvement. At this time, other less frequent aetiologies were considered.

$M$ tuberculosis, a relatively common agent in Portugal, can cause insidious meningitis with hypoglycorrhachia. However, the normal imaging studies, the negative tuberculin intradermal reaction, CSF amplification and culture did not support this diagnosis.

Viruses can also cause meningitis, namely enteroviruses and arboviruses, especially during summer months, but these were also ruled out by laboratory tests. Borrelia and Brucella infections were also excluded.

\section{TREATMENT}

Recommended treatment for rickettsial infections is doxycycline $100 \mathrm{mg}$ twice a day for 5-10 days (or at least 3 days following defervescence). ${ }^{1-9}$ Our patient completed 10 days of doxycycline.

Cephalosporins and penicillins are ineffective as observed in this case. ${ }^{9}$

\section{OUTCOME AND FOLLOW-UP}

The patient evolved favourably with remission of symptoms $24 \mathrm{~h}$ after starting doxycycline and had no sequelae.

\section{DISCUSSION}

The atypical presentation and the paucity of additional symptoms (no high fever, myalgias, rash or eschar) in this case challenged the diagnosis. Nonetheless, the epidemiological context raised the suspicion of a zoonotic infection and the positive serology for Rickettsia confirmed the diagnosis and led us to change the antibiotic therapy to doxycycline, with improvement.

The patient presented during summer and lived in a rural setting (two factors associated with the highest incidence of rickettsioses) ${ }^{6}$ and he had a history of exposure to several animals, including a squirrel and a dog. Transmission of Rickettsia might have occurred directly by one of the pets or by their vectors, such as ticks or fleas. Although no vectors were tested, the squirrel had a positive serology for Rickettsia spp. Furthermore, the lack of improvement under therapy with cefthriaxone was suggestive of infection with an atypical agent.

Owing to the presence of shared protein and lipopolysaccharide antigens, it is extremely difficult to distinguish closely related agents within the rickettsial spotted fever group by serological methods. ${ }^{16}$ Only successful isolation of the agent or molecular detection in blood or tissue can determine the Rickettsia species. ${ }^{7}$ However, this was not achievable in this case, which might be related to treatment with clarithromycin prior to admission.

Central nervous system involvement, namely rickettsial encephalitis, is characterised by confusion and obtundation due to increased intracranial pressure and has been associated with a worse prognosis. ${ }^{7}$ Our patient did not show signs of cerebral parenchymal disease.

In general, rickettsial meningitis behaves like a viral meningitis but responds only to doxycycline or chloramphenicol instead of symptomatic therapy. ${ }^{14} 17$ Our patient was medicated with clarithromycin which has demonstrated efficacy in rickettsial infections $^{18}{ }^{19}$; we hypothesise that the lack of response was due to the short duration of therapy and the erratic central nervous system penetration.

Milder presentations, such as the one described, have been reported in association with $R$ felis and $R$ helvetica. ${ }^{14} 15$ Thus far, in Portugal, $R$ felis has only been isolated in fleas. ${ }^{20} 21$ $R$ belvetica, although common in ticks, is rarely isolated in humans; it may be associated with a short-lived bacteriaemia. ${ }^{22}$
We conclude that aseptic meningitis and encephalitis should elicit the hypothesis of rickettsial infection, given its high incidence in endemic areas and diverse symptomatology. ${ }^{17}$

\section{Learning points}

- Rickettsial infection may present as meningitis and should be included in the differential diagnosis in endemic countries.

- Definitive diagnosis of rickettsial infections relies mainly on serological methods that can be limited in an initial phase (due to latency in antibody response), emphasising the need for a high clinical suspicion.

- Early treatment should be instituted empirically, since it improves prognosis, diminishes mortality and sequelae associated with rickettsioses.

- There are an increasing number of reports regarding emerging Rickettsia spp responsible for incomplete and atypical presentations that should be considered.

Contributors All authors are responsible in making substantial contributions to the intellectual content. IS participated in the conception, design, research, data acquisition and analysis and drafting the manuscript; RdS participated in conception, design, research, data analysis and interpretation, drafting the manuscript and critical revision; CG participated in conception, research, data acquisition and analysis, drafting the manuscript and critical revision.

\section{Competing interests None.}

Patient consent Obtained.

Provenance and peer review Not commissioned; externally peer reviewed.

\section{REFERENCES}

1 Eremeeva ME, Dasch GA. Rickettsial (spotted \& typhus fevers) \& related infections (anaplasmosis \& erlichiosis). In: Brunette G, ed. CDC Health Information for International Travel 2012 (The Yellow Book). CDC Health Information for International Travellers. Oxford University Press, 2011:278-84.

2 Jensenius $M$, Fournier $P$, Raoult D. Rickettsioses and the international traveller. Clin Infect Dis 2004:39:1493-9.

3 Oteo JA, Portillo A. Tick-borne rickettsioses in Europe. Ticks Tick Borne Dis 2012:3:271-8

4 Sousa R, Duque L, Anes $M$, et al. Lymphangitis in a Portuguese patient infected with Rickettsia sibirica. Emerg Infect Dis 2008;14:529-30.

5 Sousa R, Pereira BI, Nazareth C, et al. Rickettsia slovaca infection in humans, Portugal. Emerg Infect Dis 2013;19:1627-9.

6 Sousa R, Nóbrega S, Bacellar F, et al. Sobre a realidade da febre escaro-nodular em Portugal. Acta Med Port 2003;16:429-36.

7 Sousa R, França A, Nóbrega SD, et al. Host and microbial risk factors and pathophysiology of fatal Rickettsia conorii infection in Portuguese patients. I Infect Dis 2008;198:576-85.

8 Kulkarni A. Childhood rickettsiosis. Indian J Pediatr 2011;78:81-7.

9 Eremeeva ME, Dasch GA. Other Rickettsia species. In: Long SS, Pickering LK, Prober CG, eds. Principles and practice of pediatric infectious diseases. 3rd edn. Chap 179. Philadelphia, PA: Churcill Livingstone Elsevier, 2008:919-27.

10 Marcon G, Callegari E, Scevola M, et al. Acute rickettsial myocarditis. Description of a clinical case and review of the literature. G Ital Cardiol 1988;18:72-5.

11 Walker DH, Crawford CG, Cain BG. Rickettsial infection of the pulmonary microcirculation: the basis for interstitial pneumonitis in Rocky Mountain spotted fever. Hum Pathol 1980;11:263-72.

12 Schulze MH, Keller C, Müller A, et al. Rickettsia typhi infection with interstitial pneumonia in a traveler treated with moxifloxacin. J Clin Microbiol 2011;49:741-3.

13 Sirisanthana V, Puthanakit T, Sirisanthana T. Epidemiologic, clinical and laboratory features of scrub typhus in thirty Thai children. Pediatr Infect Dis J 2003;22:341-5.

14 Lindbolm A, Severinson K, Nilsson K. Rickettsia felis infection in Sweden: report of two cases with subacute meningitis and review of the literature. Scand J Infect Dis 2010;42:906-9.

15 Nilsson K, Elfving K, Páhlson C. Rickettsia helvetica in patients with meningitis, Sweden, 2006. Emerg Infect Dis 2006;16:490-2. 
16 Cwikel BJ, Ighbarieh J, Sarov I. Antigenic polypeptides of Israeli spotted fever isolates compared with other spotted fever group Rickettsiae. Ann N Y Acad Sci 1990;590:381-8.

17 Silpapojakul K, Ukkachoke C, Krisanapan S, et al. Rickettsial meningitis and encephalitis. Arch Intern Med 1991;151:1753-7.

18 Keysari A, Itzakhi A, Rubinstein $E$, et al. The in-vitro anti-rickettsial activity of macrolides. J Antimicrob Chemother 1996;38:727-31.

19 Cascio A, Colomba C, Antinori S, et al. Clarithromycin versus azithromycin in the treatment of Mediterranean spotted fever in children: a randomized controlled trial. Clin Infect Dis 2002;34:154-8.
20 Sousa R, Edouard-Fournier P, Santos Silva M, et al. Molecular detection of Rickettsia felis, Rickettsia typhi and two genotypes closely related to Bartonella elizabethae. Am J Trop Med Hyg 2006;75:727-31.

21 Pérez-Osorio C, Zavala-Vélazquez J, Léon J, et al. Rickettsia felis as an emergent global threat for humans. Emerg Infect Dis 2008;14: 1019-23.

22 Boretti FS, Perreten A, Meli ML, et al. Molecular Investigations of Rickettsia helvetica infection in dogs, foxes, humans and Ixodes ticks. Appl Environ Microbiol 2009;75:3230-7.

Copyright 2014 BMJ Publishing Group. All rights reserved. For permission to reuse any of this content visit http://group.bmj.com/group/rights-licensing/permissions.

BMJ Case Report Fellows may re-use this article for personal use and teaching without any further permission.

Become a Fellow of BMJ Case Reports today and you can:

- Submit as many cases as you like

- Enjoy fast sympathetic peer review and rapid publication of accepted articles

- Access all the published articles

- Re-use any of the published material for personal use and teaching without further permission

For information on Institutional Fellowships contact consortiasales@bmjgroup.com

Visit casereports.bmj.com for more articles like this and to become a Fellow 